\title{
PEMBUATAN ALAT PENGERING IKAN DENGAN SISTEM ALIRAN AIR PANAS BERBAHAN BAKAR BRIKET BATUBARA
}

\author{
Oleh : \\ Jantri Sirait i)
}

\begin{abstract}
A fish drying constructed making use a hot water flowing system and coal bricket as a fuel has been assembled. This system was built using the following structure: sheet metal for the outer wall, alumunium plate for the inner wall and layer of plywood, stereoform, and alumunium foil were arranged in between, and hot water cylinder made from sheet metal $(1 \mathrm{~mm})$. Hot water flowing system in the drying shelf assembled in a spiral like structure moving around the inner wall of the drying room. Fish drying system constructed making use coal bricket, and this system was able to produce dried fish with water content confirms the SNI 012721-1992 following 7 hours drying time.
\end{abstract}

Key words : fish drying system, bricket coal.

\section{PENDAHULUAN}

ndonesia dengan wilayah pesisir dan lautan yang s a ng at luas, memiliki potensi sumber daya perairan dan hayati yang dapat dikembangkan. Salah satu bentuk

olahan ikan yang banyak dikonsumsi oleh masyarakat di Indonesia adalah ikan asin kering, dimana cara pembuatannya adalah dengan cara pengeringan. Pengeringan ikan terjadi karena adanya perbedaan tekanan udara pengering dengan permukaan ikan, dan antara pengering ikan dengan bagian dalamnya. Ikan segar umumnya mengandung $80 \%$ kadar air [yunizal dkk, 1973]. Kadar air keseimbangan merupakan batas kadar air terendah yang dapat dicapai pada suhu dan kelembaban $(\mathrm{RH})$ tertentu yaitu 40-50\% [Handerson, 1955].

Pengeringan ikan yang dilakukan oleh para nelayan kita umumnya dengan memanfaatkan panas matahari (metoda tradisional) yaitu dengan menggunakan peralatan yang masih sederhana, dengan penjemuran diatas anyaman bambu. Keuntungan yang didapat pada metoda ini ialah sinar ultra violet dari panas sinar matahari berfungsi sebagai desinfektan terhadap ikan asin kering, namun demikian cara ini mempunyai sisi kelemahan yaitu intensitas sinar matahari yang tidak konstan mengakibatkan ketidak seragaman akan kering ikan dan kadar air ikan asin kering belum memenuhi standart SNI 01-2721-1992. Bila dilihat dari sisi higienis, memungkinkan terjadi kontaminasi ikan dengan debu yang beterbangan disekitar pengeringan. Masalah lain yang perlu dipertimbangkan adalah diperlukan tenaga yang relatif besar untuk mengeringkan ikan, dan butuh lahan yang luas untuk mengeringkan ikan, serta lama pengeringan ikan butuh waktu dua hingga tiga hari sehingga mengakibatkan ikan asin kering berbau busuk, dan jumlah produksi ikan asin kering yang dihasilkan para nelayan sangat kecil karena ketergantungan dengan kondisi cuaca. 
Dalam makalah ini akan dipaparkan aspek teknologi dan proses pembuatan alat pengering. Proses pembuatan alat tersebut diawali dengan desain gembar yang disesuaikan dengan aspek teknologi melalui persamaan Kreith, F. Selanjutnya dilakukan uji coba alat pengering, serta pengujian kadar air produk yang dihasilkan, dan menganalisa tekno ekonomi alat pengering tersebut.

Aspek teknologi yang dibahas dalam pembuatan alat pengering ini yaitu, panas yang hilang lewat cerobong dihitung dengan persamaan [Kreith $F$, 1991] dengan persamaan $Q L=A K\left(T_{1}^{4}-T_{2}{ }^{2}\right)$ dimana $Q L=$ panas yang hilang lewat cerobong $(\mathrm{kj} / j \mathrm{jam}), \quad A=$ Luas bidang pancaran $\left(\mathrm{m}^{2}\right), \mathrm{k}=$ konstanta $\left(2,04 \times 10^{7} \mathrm{~kJ} / \mathrm{Jam} \mathrm{m}^{2}{ }^{\circ} \mathrm{K}\right), \mathrm{T}_{1}{ }^{4}=$ kali Suhu pada bidang pancaran $\left({ }^{\circ} \mathrm{K}\right), \mathrm{T}_{2}{ }^{4}=$ Suhu lingkungan ( $\left.{ }^{\circ} \mathrm{K}\right)$, dan panas yang hilang lewat ventilasi tungku dihitung dengan persamaan [Kreith $F, 1991$ ] dengan persamaan $Q C=$ Wu $C p$ " $T$, dimana $Q C=$ Panas yang hilang melalui ventilasi tungku $(\mathrm{kJ} / \mathrm{Jam}), \mathrm{WU}=$ Debit udara yang mengalir $(\mathrm{kJ} / \mathrm{Jam}), \mathrm{Cp}=$ Koefisien panas jenis udara $\left(\mathrm{kJ} / \mathrm{kg}{ }^{\circ} \mathrm{c}\right),{ }^{\prime} \mathrm{T}=$ Selisih antara suhu udara pembakaran dengan suhu udara keluar pipa pemanas $\left({ }^{\circ} \mathrm{C}\right)$.

\section{BAHAN DAN METODA}

Pengumpulan data dilakukan dengan cara survey dan wawancara langsung dengan para nelayan dilokasi pesisir pantai dan sungai, khususnya di Kalimantan Timur yang banyak menghasilkan ikan, seperti Muara Badak, Kota Bangun, Muara Mungtai dan beberapa Kabupaten Kota lainnya, untuk mengetahui kendala - kendala yang dialami para nelayan dalam mengeringkan ikan, $\mathrm{Hal}$ ini dilakukan sebelum desain gambar dan pembuatan alat pengering.

Dari hasil survey dan wawancara dengan para nelayan maka dibuat suatu alat pengering, dimana alat pengering tersebut dapat digunakan tanpa ketergantungan dengan kondisi cuaca dan alat pengering dapat digunakan dengan dua cara yaitu dengan cara menggunakan rak pengering dan menggunakan gantur.gan. Desain alat pengering ini untuk ikan besar dan kecil yang akan dikeringkan, dimana ikan yang kecil dikeringkan dengan menggunakan rak pengering dan untuk ikan yang besar dipergunakan sistem gantungan. Desain alat pengering ini dibuat dengan harga yang murah agar terjangkau oleh para nelayan, sehingga dapat meningkatkan pendapatan para nelayan. Bahan - bahan yang dipergunakan dalam percobaan alat pengering adalah ikan bandeng sebagai media yang dikeringkan, garam sebagai bahan pengawet ikan, ember plastik untuk tempat membersihkan ikan, karung plastik guna tempat ikan yang sudah kering, briket batubara sebagai bahan bakar dan minyak tanah sebagai pembanding kebutuhan bahan bakar. Pemilihan ikan bandeng sebagai media yang dikeringkan karena ikan bandeng memiliki bentuk yang besar dan memiliki daging yang cukup tebal. Panas yang dibutuhkan guna mengeringkan ikan antara $45-50$ ${ }^{\circ} \mathrm{C}$, dimana ikan yang dikeringkan apabila dibawah $45^{\circ} \mathrm{C}$ mengakibatkan hasil ikan kering mengerut dan apabila diatas $50^{\circ} \mathrm{C}$ mengakibatkan pengerasan bagian luar ikan kering.

Adapun prosedur pengoperasian alat pengering antara lain ; tungku bahan bakar diisi dengan air bersih sebanyak 75 liter, kemudian dipanaskan dengan menggunakan briket batubara, selanjutnya pompa air dihidupkan dan keran masuk dibuka serta keran pengembali dibuka. Biarkan suhu ruangan pengering sampai mencapai $45-50^{\circ} \mathrm{C}$ baru ikan yang akan dikeringkan dimasukkan kedalam pengering dengan cara disusun diatas rak pengering atau digantung sesuai dengan kebutuhan. Selanjutnya hidupkan blower dan buka ventilasi udara guna membuang uap air keluar dari ikan dan guna menjaga kestabilan suhu ruangan pengering stabil pada suhu $45-50{ }^{\circ} \mathrm{C}$. Lakukan pengecekan terhadap ikan yang dikeringkan,apabila sudah kering keluarkan ikan dari dalam rak pengering dan dinginkan ditempat yang bersih dan masukkan kembali ikan yang akan dikeringkan. Kemas ikan setelah didinginkan. 


\section{HASIL DAN PEMBAHASAN}

Pada Gambar 1 ditampilkan desain dinding alat pengering yang terdiri dari : pandangan depan, samping kanan, samping kiri, belakang, atas, dan bawah. Dinding luar pengering terbuat dari plat besi $1 \mathrm{~mm}$, pada lapisan kedua dipakai plywood $3 \mathrm{~mm}$, kemudian pada lapisan ketiga dipasang steroform $3 \mathrm{~mm}$, baru dilapisi dengan aluminium foil, dan dinding bagian dalam dilapisi dengan plat alumunium guna menjaga panas yang di dalam ruang pengering tidak menyebar keluar.

Spesifikasi alat pengering yang dibuat dengan tinggi alat pengering $110 \mathrm{~cm}$, panjang 100 $\mathrm{cm}$, lebar $100 \mathrm{~cm}$, dan jumlah rak pengering 8 rak. Kapasitas tungku air pemanas sebanyak 75 liter dengan ukuran tinggi $50 \mathrm{~cm}$ dengan $\varnothing 40 \mathrm{~cm}$, dan tinggi kaki tungku $105 \mathrm{~cm}$, pompa air $2850 \mathrm{rpm}$ Watt 125 Out Put $35 \mathrm{~L} /$ menit, serta blower $3600 \mathrm{rpm} 220$ volt $1 \mathrm{Amp}$, dan untuk pipa pengalir air panas dipakai pipa kuningan sepanjang $155 \mathrm{~m}$ dengan ukuran 1'. Pemilihan spesifikasi ini disesuaikan dengan hasil tangkap para nelayan, dimana hasil tangkap nelayan masih kecil karena mempergunakan peralatan yang masih sederhana.

Pada Gambar 2 tampilkan sistem aliran air panas. Pipa aliran air panas didalam ruang pengering disusun dengan sistem spiral. Air panas dipompa dari tungku menuju pipa dinding bawah, kemudian kepipa dinding kiri, selanjutnya ke pipa dinding belakang, kemudian kepipa dinding kanan, dan yang terakhir kepipa dinding atas dan seterusnya sirkulasi kembali ke tungku pemanas. Desain aliran air panas dengan sistem spiral dengan jarak pipa $8 \mathrm{~cm}$, bertujuan untuk mempercepat penyebaran panas didalam ruangan pengering. Pipa aliran air panas dipasang kawat untuk mempercepat pemerataan transfer panas didalam ruangan pengering.

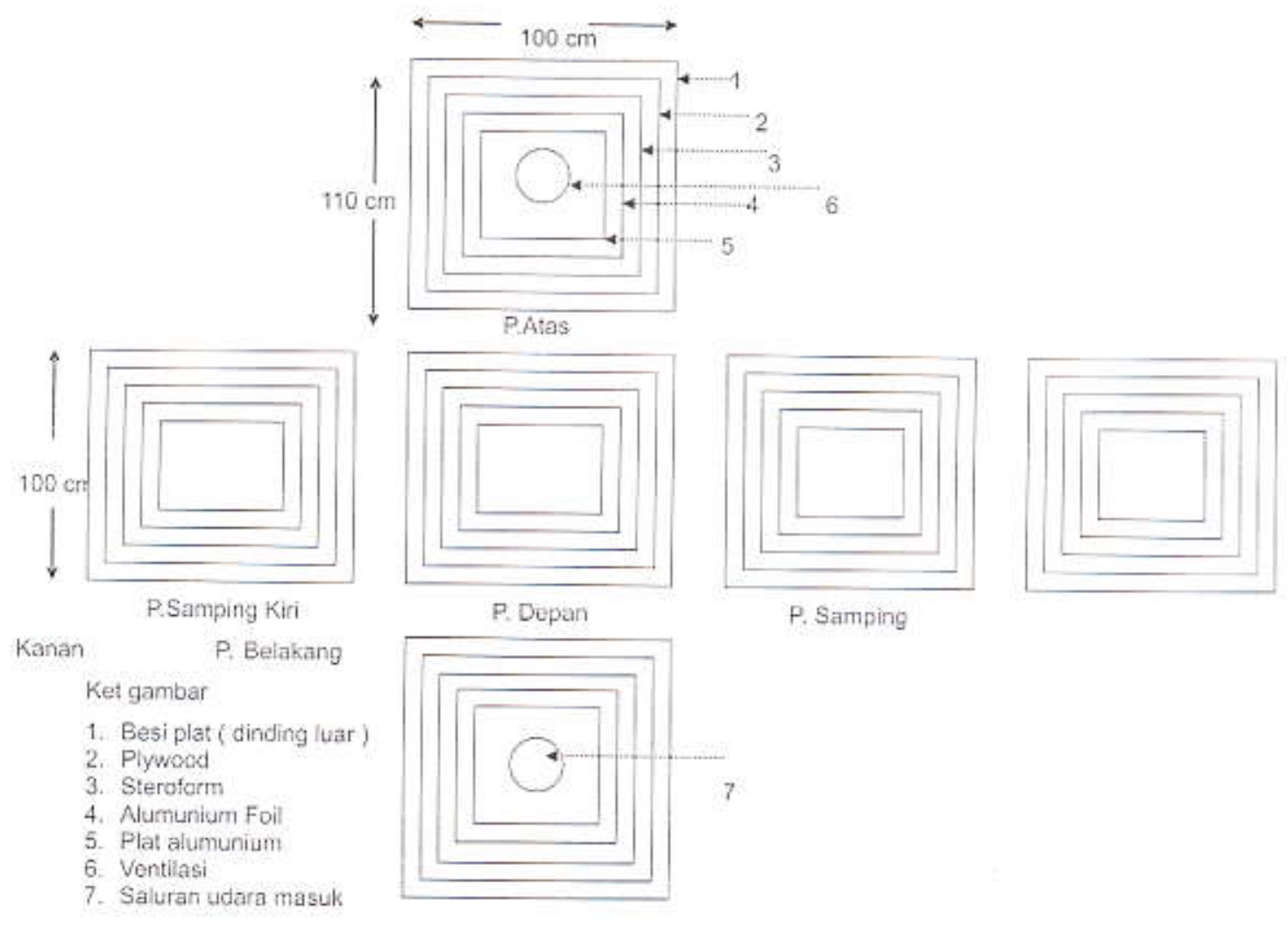

Gambar 2. Pandangan alat pengering dan lapisannya 


\section{KET. GAMBAR :}

1. Pengisian air

2. Cerobong

3. Ventilasi

4. Keran out $\left(1,5^{\prime \prime}\right)$

5. Pipa (kuningan 1")

6. Ventilasi

7. Tungku (plat $5 \mathrm{~mm}$ )

8. Keran in $\left(1,5^{*}\right)$

9. Kompor

10. Pompa air

(125 watt/ $2850 \mathrm{rpm}$ )

11. Kawat pemerata $(1 \mathrm{~mm})$

12. Blower

(220 volt/ $3600 \mathrm{rpm}$ )

13. Selang udara ( 3 ")

14. Saluran udara masuk

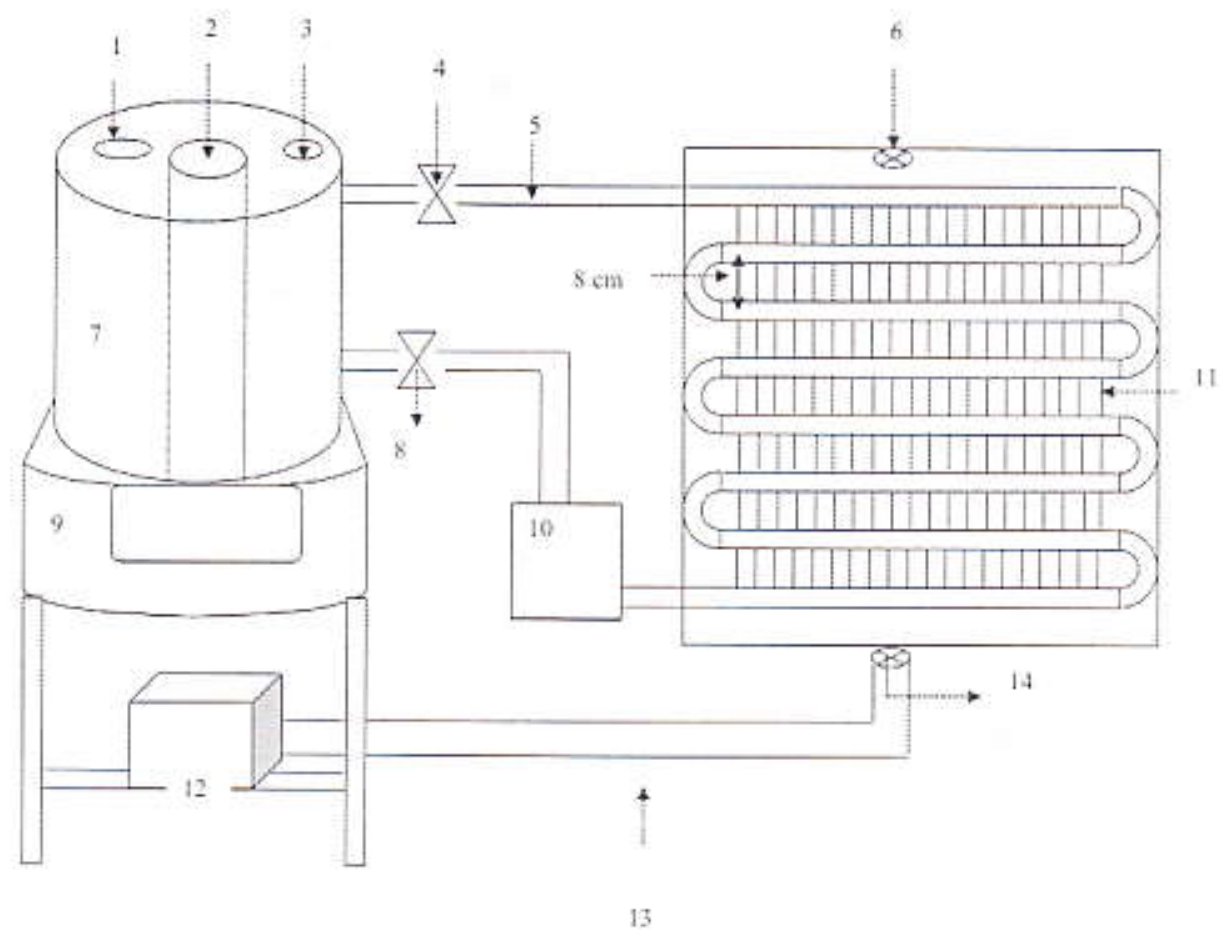

Pada Gambar 2. Ditampilkan suatu alat pengering ikan dengan sistem aliran air panas berbahan bakar briket batubara

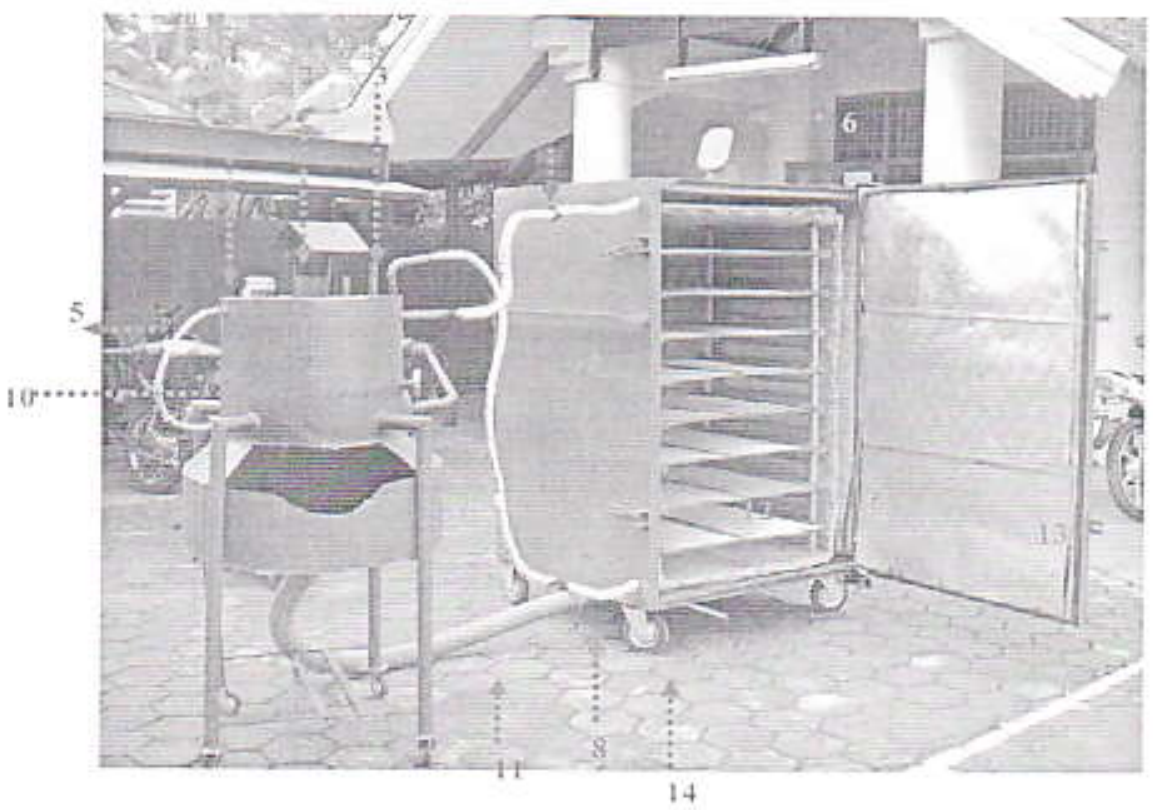

Gambar 3. Alat pengering ikan dengan sistem aliran panas

\section{Keterangan gambar :}

1. Lubang pengisian air

2. Lubang pembuangan asap

3. Lubang pembuangan uap

4. Tungku pemanas

5. Selang ukur stabil air

6. Ventilasi

7 . Pipa pengembali
8. Pipa masuk air

9. Tungku pemanas

10. Thermometer

11. Selang masuk udara

12. Rak pengering

13. Pintu pengering

14. Roda 
Panas yang hilang lewat cerobong yang dihitung dengan menggunakan persamaan 1 dapat dilihat pada tabel 1.

Tabel 1. Panas yang hilang melalui cerobong

\begin{tabular}{|c|c|c|c|c|}
\hline $\mathrm{QL}(\mathrm{kJ} / \mathrm{jam})$ & $\mathrm{A}\left(\mathrm{m}^{2}\right)$ & $\mathrm{T}_{1}{ }^{4}\left({ }^{\circ} \mathrm{K}\right)$ & $\mathrm{T}_{2}{ }^{4}\left({ }^{\circ} \mathrm{K}\right)$ & $\mathrm{k}\left(\mathrm{kJ} / \mathrm{Jam} \mathrm{m}^{2}{ }^{\circ} \mathrm{K}\right)$ \\
\hline 238,0254 & 0,175 & $374^{4}$ & $337^{4}$ & $2,04 \times 10^{-7}$ \\
\hline
\end{tabular}

Panas yang keluar dari cerobong sebelum ke udara luar berfungsi untuk memanaskan air pada permukaan air, karena titik didih air bagian atas lebih rendah dari titik didih air didasar tungku, hal ini terjadi karena panas air yang mengalir telah diserap oleh dinding pemanas. Panas yang hilang lewat ventilasi tungku dihitung dengan persamaan 2 dapat dilihat pada tabel 2.

Tabel 2. Panas yang hilang lewat ventilasi tungku

\begin{tabular}{|c|c|c|c|}
\hline QC $(\mathrm{Kj} / \mathrm{jam})$ & Wu $(\mathrm{Kj} / \mathrm{jam})$ & $\mathrm{Cp}\left(\mathrm{Kj} / \mathrm{kg}^{\circ} \mathrm{C}\right)$ & $\Delta \mathrm{T}\left({ }^{\circ} \mathrm{C}\right)$ \\
\hline 1913,42 & 62,53 & 1,02 & 30 \\
\hline
\end{tabular}

Pembuangan uap panas dari dalam tungku untuk menghindari tekanan panas yang dapat mengakibatkan tungku pemanas pecah. Percobaan alat yang pertama dilakukan dengan menggunakan bahan bakar minyak tanah. Ikan yang dikeringkan adalah ikan bandeng seberat 80 $\mathrm{kg}$, dengan cara disusun diatas rak dan waktu pengeringan selama 7 jam, hasil ikan kering kurang bagus karena permukaan ikan rusak. Pada percobaan kedua dilakukan dengan menggunakan bahan bakar briket batubara, ikan yang dikeringkan seberat $80 \mathrm{~kg}$, dan lama pengeringan 7 jam. Hasil ikan yang dikeringkan bagus karena menggunakan gantungan. Untuk mengetahui nilai ekonomis pemakaian bahan bakar dapat dilihat pada tabel 3 .

Tabel 3. Perbandingan pemakaian briket batubara dengan minyak tanah

\begin{tabular}{|c|c|c|c|c|c|}
\hline No & Bahan Bakar & $\begin{array}{c}\text { Jumlah } \\
\text { Pemakaian }\end{array}$ & $\begin{array}{c}\text { Lama Pemanasan } \\
\text { awal sampai suhu } \\
100^{\circ} \mathrm{C} \text { (menit) }\end{array}$ & $\begin{array}{l}\text { Lama pengeringan } \\
\text { pada suhu } \\
45 \quad 50^{\circ} \mathrm{C} \text { (menit) }\end{array}$ & $\begin{array}{c}\text { Harga Satuan } \\
\text { (Rp) }\end{array}$ \\
\hline 1 & Minyak Tanah & 18 liter & 120 & 420 & $3500 /$ liter \\
\hline 2 & $\begin{array}{l}\text { Briket } \\
\text { Batubara }\end{array}$ & 9 biji & 80 & 420 & $1250 /$ biji \\
\hline
\end{tabular}

Pemakaian bahan bakar briket batubara sangat ekonomis bila dibandingkan dengan penggunaan bahan bakar minyak tanah. bila ditinjau dari segi harga penggunaan bahan bakar minyak tanah butuh biaya Rp 63.000 ,- dengan menggunakan bahan bakar briket batubara butuh biaya Rp 11.250,-- 
Dari hasil uji coba alat dilakukan pengujian hasil percobaan dilaboratorium dengan para meter kadar air. Hal ini dapat dilihat pada tabel 4.

Tabel 4. Pengaruh waktu pengeringan terhadap kadar air ikan dengan bahan bakar briket batubara.

\begin{tabular}{|c|c|c|}
\hline $\begin{array}{c}\text { Waktu Pengeringan } \\
\text { (Jam) }\end{array}$ & $\begin{array}{c}\text { Kadar air hasil Uji } \\
(\%)\end{array}$ & $\begin{array}{l}\text { Standard SNI } \\
012721-1992\end{array}$ \\
\hline 3 & 64,56 & \multirow{5}{*}{$40 \%$} \\
\hline 4 & 51,85 & \\
\hline 5 & 46,85 & \\
\hline 6 & 45,45 & \\
\hline 7 & 39,34 & \\
\hline
\end{tabular}

Dari hasil percobaan tersebut maka kadar air yang memenuhi standard SNI 021721-1992 adalah lama pengeringan dengan waktu 7 jam. Dengan berhasilnya pembuatan aiat pengering, dan uji coba alat serta pengujian hasil produk ikan kering telah dilakukan, maka pada makalah ini dibahas tekno ekonomi alat pengering ikan dengan sistem aliran air panas.

Berat ikan kering $x 20$ hari kerja/bulan x persentasi kadar air ikan segar $x$ harga ikan $/ \mathrm{kg} \times 1$ tahun, kemudian biaya bahan baku dan penolong adalah berat ikan bandeng $\times 20$ hari kerja $x$ harga ikan $/ \mathrm{kg}$, sedangkan untuk upah tenaga kerja langsung adalah 2 orang tenaga kerja $\times 20$ hari kerja $\times 20.000$ / hari, dan untuk overhead pabrik dapat dihitung dengan kebutuhan 9 biji briket batubara $x$ 20 hari kerja $x$ harga briket batubara Rp 1250,00, juga kebutuhan karung plastik untuk tempat ikan yang sudah dikeringkan 6 lembar karung plastik $\times 20$ hari kerja $\times$ harga karung pelastik / lembar, begitu juga dengan kebutuhan air bersih yaitu 5 drum / hari $\times 20$ hari lama pengopersaian alat / bulan. dan juga biaya penyusutan alat terhitung yaitu jumlah biaya tetap $\times 0,1 \times 10 \%: 1$ tahun.dan juga untuk biaya perawatan alat yaitu harga penyusutan alat $x 3 \%: 1$ tahun. berat ikan kering $x$ 20 hari kerja / bulan $x$ persentasi kadar air ikan segar $\times$ harga ikan / $\mathrm{kg} \times 1$ tahun, kemudian biaya bahan baku dan penolong adalah berat ikan bandeng $\times 20$ hari kerja $x$ harga ikan $/ \mathrm{kg}$, sedangkan untuk upah tenaga kerja langsung adalah 2 orang tenaga kerja $\times 20$ hari kerja $\times 20.000$ / hari, dan untuk overhead pabrik dapat dihitung dengan kebutuhan 9 biji briket batubara $\times 20$ hari kerja $\mathrm{x}$ harga briket batubara Rp 1250,00, juga kebutuhan karung plastik untuk tempat ikan yang sudah dikeringkan 6 lembar karung plastik $\times 20$ hari kerja $\times$ harga karung pelastik / lembar, begitu juga dengan kebutuhan air bersih yaitu 5 drum / hari $\times 20$ hari lama pengopersaian alat / bulan. dan juga biaya penyusutan alat terhitung yaitu jumlah biaya tetap $\times 0,1 \times 10 \%: 1$ tahun.dan juga untuk biaya perawatan alat yaitu harga penyusutan alat $x 3 \%: 1$ tahun. Hal ini dapat dilihat pada tabel 5 . 
Tabel 5. Tekno ekonomi alat pengering

\begin{tabular}{|c|l|l|}
\hline No & \multicolumn{1}{|c|}{ Uraian } & \multicolumn{1}{c|}{ Jumlah } \\
\hline 1 & Hasil Produksi 1 Tahun & $19200 \mathrm{~kg}$ \\
\hline 2 & Biaya Produksi 1 Tahun & Rp $652.743 .270 .-$ \\
\hline 3 & Biaya Variabel 1 tahun & Rp 593.880 .000 \\
\hline 4 & Biaya tetap 1 tahun & Rp 58.863 .270 \\
\hline 5 & Penjualan 1 tahun & Rp 768.000 .000 \\
\hline 6 & BEP ( \%) & $33,81 \%$ \\
\hline 7 & BEP (Rp) & Rp. 259.631.239 \\
\hline 8 & BEP ( Q) & 6,491 \\
\hline 9 & Perhitungan balik modal & $44,85 \%$ \\
\hline 10 & Waktu balik modal & 2 Tahun 3 Bulan \\
\hline
\end{tabular}

\section{KESIMPULAN DAN SARAN}

Penggunaan rak pengering sebaiknya dihindari, karena rak dapat mengakibatkan permukaan ikan yang dikeringkan rusak karena lengket ke rak pengering, hal ini disebabkan karena rak pengering panas. Waktu pengeringan ikan hendaknya menggunakan gantungan, untuk menghindari kerusakan permukaan ikan. Penggunaan bahan bakar briket batubara sebagai sumber panas sangat ekonomis dibanding dengan menggunakan minyak tanah, karena harga briket batubara lebih murah dari pada harga minyak tanah, dan pemakaian briket batubara lebih irit dibanding dengan pemakaian minyak tanah.

Untuk mengghindari permukaan ikan rusak, apabila ikan yang dikeringkan besar gunakan sistem gantungan. Apabila ikan yang dikeringkan kecil gunakan rak pengering. Untuk menghindari kerusakan pada ikan yang dikeringkan jaga suhu rungan pengering pada suhu 45 $50^{\circ} \mathrm{C}$.

\section{DAFTAR PUSTAKA}

Endang Sri Nuryani, H. Hartanto, Soedjono. 1994. Cara Kerja Ketel Uap. Mugantara Bandung Henderson, S.Mand Perry, R.L.1955. Agricultural Process Engineering. New York: John Willey. Kreith,F, 1991. Prinsip-Prinsip Perpindahan Panas. Erlangga Jakarta Reynolds, C.W dan H.C.Perkins, 1991. Thermodinamika Teknik. Erlangga Jakarta Yunizal, Wahyudi, dan Mulyadi.1973. Suatu percobaan pengering ikan dengan cara mekanis dan penyimpanan pada suhu rendah. Balai Penelitian Teknologi Perikanan, Jakarta 